\title{
MENINGKATKAN KETERAMPILAN MENULIS KARANGAN DESKRIPSI MELALUI MODEL PEMBELAJARAN CTL PADA SISWA KELAS V DI SDN 101766 BANDAR SETIA
}

\author{
Erlinda Simanungkalit, Riri Dwi Putri \\ Surel: erlindapgsdunimed@gmail.com
}

\begin{abstract}
This study aims to improve the writing essay skills through the CTL learning model for fifth grade students in 101766 Public Elementary School Bandar Setia T.A 2017/2018. CTL learning model is a learning model by linking between subject matter with real life that occurs in the environment of students. This research is in the form of Classroom Action Research. The subjects of this study were fifth grade students of state elementary school 101766 Bandar Setia. Based on the results of the study of writing essay studies using the CTL learning model can improve the skills of writing description essays can be seen from the value of writing descriptions of students in pre-cycle, cycle I and cycle II which increases. The average score of the essay writing test in the initial conditions is 61.73 with classical completeness of $30.76 \%$ in the first cycle of the class average value to 70.76 with the classical percentage of 65.38\%. In the second cycle the average value of the class becomes 80.00 with a classical percentage of $88.46 \%$. The researcher hereby states that the use of the CTL learning model in the second cycle of success has reached $85 \%$ so that the learning process using the CTL learning model is successful.
\end{abstract}

Keywords : Skills, Writing, Learning, Contextual Teaching And Learning.

\begin{abstract}
ABSTRAK
Penelitian ini bertujuan untuk meningkatkan keterampilan menulis karangan deskripsi melalui model pembelajaran CTL pada siswa kelas V di SD Negeri 101766 Bandar Setia. Model pembelajaran CTL merupakan model pembelajaran dengan mengaitkan antara materi pelajaran dengan kehidupan nyata yang terjadi di lingkungan peserta didik. Penelitian ini berbentuk Penelitian Tindakan Kelas. Subjek penelitian ini adalah siswa kelas V SD negeri 101766 Bandar Setia. Hasil penelitian pembelajaran menulis karangan deskripsi dengan menggunakan model pembelajaran CTL dapat meningkatkan keterampilan menullis karangan deskripsi dapat dilihat dari nilai menulis karangan deskripsi siswa pada pra siklus, siklus I dan siklus II yang meningkat. Nilai rata-rata tes menulis karangan deskripsi pada kondisi awal 61,73 dengan ketuntasan klasikal 30,76\% pada siklus I nilai rata-rata kelas menjadi 70,76 dengan persentase klasikal 65,38\%. Pada siklus II nilai rata-rata kelas menjadi 80,00 dengan persentase klasikal 88,46\%. Peneliti dengan ini menyatakan Penggunaan model pembelajaran CTL pada siklus II persentase keberhasilannya sudah mencapai $85 \%$ sehingga proses pembelajaran menggunakan model pembelajaran CTL berhasil.
\end{abstract}

Kata kunci : Keterampilan, Menulis, Pembelajaran, Contextual Teaching And Learning. 



\section{PENDAHULUAN}

Bahasa Indonesia merupakan salah satu pelajaran yang memiliki peranan penting dalam dunia pendidikan. Dalam pengajaran bahasa Indonesia, terdapat empat keterampilan berbahasa yang terdiri atas: keterampilan menyimak, keterampilan berbicara, keterampilan membaca, dan keterampilan menulis. Keempat keterampilan tersebut saling bertalian satu sama lain. Mulamula pada masa kecil kita belajar menyimak dan berbicara dipelajari sebelum memasuki jenjang di sekolah, sedangkan membaca dan menulis merupakan satu kesatuan atau merupakan catur tunggal. Selanjutnya pengajaran bahasa Indonesia perlu dilakukan sejak dini, yakni mulai tingkat sekolah dasar (SD) yang nantinya berguna saebgai landasan untuk jenjang tingkat lanjut juga sebagai upaya untuk meningkatkan mutu penggunaan bahasa tersebut.

Kegiatan menulis adalah salah satu kegiatan yang tidak bisa dipisahkan dari proses belajar yang dialami oleh siswa. Dimana kegiatan menulis ini menuntut banyak keterampilan. Dalam Kamus Besar Bahasa Indonesia (2002:1180) bahwa kata terampil adalah cakap dalam menyelesaikan tugas, mampu dan cekatan. Sedangkan keterampilan adalah kecakapan untuk menyelesaikan tugas, kecakapan seseorang untuuk memakai bahasa dalam menulis, membaca, menyimak atau berbicara.
Menurut Soemardji dkk, (2001:2) menuliskan bahwa kata terampil sama artinya dengan kata cekatan. Terampil atau cekatan adalah kepandaian melakukan sesuatu pekerjaan dengan cepat dan benar. Ruang lingkup keterampilan cukup luas meliputi kegiatan berupa perbuatan, berpikir, berbicara, melihat, mendengar. Jadi dapat disimpulkan bahwa keterampilan merupakan suatu bentuk kemampuan yang mempergunakan pikiran dan perbuatan dalam menyelesaikan atau mengerjakan sesuatu dengan efektif dan efisien. Keterampilan juga dapat diartikan sebagai suatu kemampuan dan kapasitas yang diperoleh melalui usaha yang sistematis dan berkelanjutan secara lancar dan adaptif dalam melaksanakan aktivitas-aktivitas yang kompleks atau fungsi pekerjaan yang melibatkan ide-ide atau keterampilan kognitif, hal-hal atau keterampilan teknikal, dan orang-orang atau keterampilan interpersonal.

Nida dan Harris (dalam Tarigan, 2005:1) mengatakan bahwa keterampilan berbahasa mempunyai empat komponen, yaitu: a) Keterampilan menyimak (listening skills), b) keterampilan berbicara (speaking skills), c) Keterampilan membaca (reading skills), d) keterampilan menulis (writing skills). Setiap keterampilan itu erat sekali dengan tiga keterampilan lainnya dengan cara yangberaneka ragam.

Tarigan (2005:22) pada prinsipnya fungsi utama dari tulisan adalah sebagai alat komunikasi yang 
tidak langsung. Menulis sangat penting bagi pendidikan karena memudahkan para pelajar berpikir. Juga dapat menolong kita berpikir kritis. Juga dapat memudahkan kita merasakan dan menikmati hubunganhubungan, memperdaya daya takap atau persepsi kita, memecahkan masalah-masalah yang dihadapi, menyusun urutan bagi pengalaman.

Karangan merupakan karya tulis hasil dari kegiatan seseorang untuk mengungkapkan gagasan dan menyampaikannya melalui bahasa tulis kepada pembaca untuuk dipahami. Karangan merupakan hasil akhir dari pekerjaan merangkai kata, kalimat, dan alinea untuk menjabarkan atau mengulas topik dan tema tertentu. Menurut Kosasih (2017:9) karangan adalah bentuk tulisan yang mengungkapkan pikiran dan perasaan pengarang suatu kesatuan tema yang utuh. Karangan diartikan pula dengan rangkaian hasil pemikiran dan ungkapan perasaaan ke dalam bentuk tulisan yang teratur.

Karangan tidak hanya terdapat satu jenis saja, namun ada banyak jenis-jenis karangan. Pada ahli mengungkapkan pendapat yang berbeda-beda mengenai banyaknya jenis-jenis karangan. Menurut Atmazaki (dalam Dalman, 2015:73) karangan terdiri dari beberapa jenis, a) Karangan deskripsi, b) Karangan argumentasi, c) Karangan eksposisi, d) Karangan narasi, dan e) Karangan persuasi.

Sebelum kita membahas tentang model pembelajaran, terlebih dahulu akan kita kaji apakah yang dimaksud dengan model? Secara kaffah model dimaknakan sebagai suatu objek atau konsep yang digunakan untuk mempresentasikan sesuatu hal. Sesuatu yang nyata dan dikonversi untuk suatu bentuk yang lebih konprehensif Meyer, W.J (didalam Trianto, 2014:23).

Model dalam Kamus Besar Bahasa Indonesia (1995) diartikan sebagai pola dari sesuatu yang akan dihasilkan atau dibuat. Sedangan menurut Indrawati (2011:1) menjelaskan bahwa model juga biasa dikenal dengan istilah pola. Model atau pola biasanya digunakan sebagai acuan atau pedoman untuk membuat, merancang, atau melaksanakan sesuatu kegiatan agar hasilnya sesuai dengan yang diharapkan. Istilah pembelajaran merupakan perkembangan dari istilah pengajaran. Pembelajaran adalah upaya yang dilakukan oleh seorang guru atau yang lain untuk membelajarkan siswa yang belajar. Menurut Munandar (dalam Suyono dan Hariyanto, 2011:207) yang menyatakan bahwa pembelajaran dikondisikan agar mampu mendorong kreativitas anak secara keseluruhan, membuat peserta didik aktif, mencapai tujuan pembelajaran secara efektif dan berlangsung dalam kondisi menyenangkan. Kondisi lingkungan sekitar dari siswa sangat berpengaruh terhadap kreativitas yang akan diciptakan oleh siswa. Disaat ketika siswa merasa nyaman, maka tujuan pembelajaran akan lebih mudah untuk dicapai. 
CTL (Contextual Teaching And Learning) adalah sebuah proses pendidikan yang bertujuan menolong para siswa melihat makna di dalam materi akademik yang mereka pelajari dengan cara menghubungkan subjek-subjek akademik dengan konteks dalam kehidupan keseharian mereka, yaitu dengan konteks keadaan pribadi, sosial dan budaya mereka.

Model pembelajaran CTL (Contextual Teaching And Learning)adalah model pembelajaran yang melibatkan para siswa dalam mencari makna "konteks" itu sendiri. CTL (Contextual Teaching And Learning) adalah proses pendidikan yang bertujuan menolong para siswa melihat makna di dalam materi akademik yang mereka pelejari dengan menghubungkan subjeksubjek akademik dengan konteks dalam kehidupan keseharian mereka.

\section{METODE PENELITIAN}

Jenis penelitian ini adalah Penelitian Tindakan Kelas (Classroom Action Research), atau biasa disebut sebagai PTK. Suyanto (dalam Dewi, 2015:9) mengatakan Penelitian Tindakan Kelas didefinisikan sebagai suatu bentuk penelitian yang bersifat reflektif dengan melakukan tindakan-tindakan tertentu agar dapat memperbaiki dan meningkatkan praktek-praktek pembelajaran di kelas secara lebih professional. Salah satu bentuk tindakannya adalah melalui metode pembelajaran.
Subjek dalam penelitian ini adalah siswa kelas VA SD Negeri 101766 Bandar Setia tahun ajaran 2017/2018, yang berjumlah 26 siswa yang terdiri dari 10 siswa laki-laki dan 16 siswa perempuan.

Adapun objek penelitian ini adalah keterampilan menulis siswa dalam pokok materi pengamatan objek langsung melalui model pembelajaran Contextual Teaching and Learning (CTL).

Penelitian ini berbentuk Penelitian Tindakan Kelas (classroom action research). Seluruh tahapan yang dilakukan dalam PTK ini merupakan tindakan yang membentuk siklus. Untuk lebih lengkapnya, berikut ini akan dikemukakan Penelitian ini menggunakan model yang dikemukakan oleh Kemmis dan Mc Taggart. Untuk lebih jelasnya, berikut ini bentuk desainnya seperti yang dikemukakan Kemmis dan Mc Taggart (dalam Hamzah B.Uno dkk, 2011: 87).

Apabila dicermati, model yang dikemukakan oleh Kemmis \& McTaggart pada hakikatnya berupa perangkat-perangkat atau untaianuntaian dengan satu perangkat terdiri dari empat komponen, yaitu perencanaan, tindakan, pengamatan,dan refleksi. Keempat komponen yang berupa untaian tersebut dipandang sebagaisatu siklus. Oleh karena itu, pengertian siklus pada kesempatan ini adalah suatuputaran kegiatan yang terdiri dari perencanaan, tindakan, observasi, dan refleksi. 
Penelitian ini berbentuk penelitian tindakan kelas. Setiap siklus dalam desain pelaksanaannya meliputi perencanaan, pelaksanaan tindakan, observasi, dan refleksi. Berikut penjelasan dari masingmasing kegiatan. Pengamatan direncanakan secara bersamaan dengan tahap pelaksanaan yaitu, ketika proses belajar mengajar berlangsung. Kegiatan yang diamati meliputi aktivitas guru dan siswa dalam pembelajaran. Pengamatan ini bertujuan untuk mengetahui kesesuaian tindakan dengan rencana yang telah disusun dan guna mengetahui sejauh mana pelaksanaan tindakan berupa pengajaran dengan menerapkan CTL (Contextual Teaching and Learning). Pengamatan ini untuk melihat apakah kondisi belajar mengajar sudah terlaksana sesuai dengan program yang diberikan. Refleksi dilakukan berdasarkan hasil analisis data observasi di dalam kelas. Refleksi ini dilakukan untuk melakukan perbaikan di siklus selanjutnya. Maka peneliti mengevaluasi kegiatan yang dilakukan.Melakukan refleksi untuk menyusun dan merumuskan tindakan-tindkan perbaikan pada siklus selanjutnya jika belum mencapai indikator keberhasilan sebagai upaya penyempurnaan. Observasi dilakukan untuk mengamati seluruh kegiatan dan perubahan yang terjadi pada saat dilakukan tindakan. Observasi yang dilakukan berupa pengamatan terhadap seluruh kegiatan proses belajar mengajar dan bertujuan untuk mengetahui perubahan yang terjadi saat dilakukan tindakan. Observasi dilakukan terhadap guru dan siswa. Analisa data dalam penelitian ini menggunakan metode analisis deskriptif kualitatif dan kuantitatif. Tujuan analisis ini adalah untuk membuat gambaran secara sistematis data yang faktual dan akurat mengenai fakta-fakta serta hubungan antar fenomena yang diselidiki atau diteliti. Analisis deskriptif adalahanalisis yang menggunakan suatu data yang akan dibuat sendiri maupun dibuatsecara berkelompok (Riduwan dan Akdon, 2007: 27).

\section{HASIL PENELITIAN DAN PEMBAHASAN}

Tahap ini disebut tahap pratindakan yaitu sebagai langkah pertama sebelum dilakukan perencanaan dan pelaksanaan tindakan terhadap siswa. Data pra siklus diperoleh saat melakukan observasi sebelum penelitian dilaksanakan dengan mengamati proses pembelajaran Bahasa Indonesia pada materi menulis karangan deskripsi. Bertujuan dilakukannya tes awal (pretest) adalah untuk mengetahui kondisi awal dan kemampuan siswa dalam menulis karangan deskripsi.Subjek penelitian peneliti adalah siswa kelas V SD negeri 101766 Bandar setia yang berjumlah 26 siswa, dengan jumlah masing-masing 10 siswa lakilaki dan 16 siswa perempuan. Tujuan dilakukannya tes awal (pretest) adalah untuk mengetahui 
keterampilan yang dimiliki setiap siswa dalam menulis karangan deskripsi, serta untuk mengetahui kemampuan siswa dalam penulisan kalimat dan tanda baca khususnya pada mata pelajaran Bahasa Indonesia.

Berdasarkan hasil nilai tes awal (pretest) yang dilakukan peneliti pada pra tindakan, hanya sebagian kecil siswa yang terampil menulis karangan deskripsi mencapai nilai KKM.dan secara klaksikal, perolehannilai siswa belum mencapai $85 \%$ sesuai dengan nilai ketuntasan kelas yang telah ditentukan. Berikut data hasil rekapitulasinilai tes awal (pretest) siswa.

Berdasarkan observasi awal yang dilakukan peneliti, dapat diketahui bahwa keterampilan menulis karangan deskripsi siswa pada mata pelajaran Bahasa Indonesia masih tergolong rendah. Hal ini disebabkan karena model pembelajaran yang digunakan kurang memotivasi siswa dalam meningkatkan keterampilan menulis karangan deskripsi sehingga kurangnya minat siswa dalam menulis pada pelajaran Bahasa Indonesia pada materi karangan deskripsi. Oleh karena itu, untuk mengatasi masalah tersebut peneliti menggunakan model pembelajaran Contextual Teaching and Learning (CTL) untuk meningkatkan keterampilan siswa dalam menulis karangan deskripsi pada mata pelajaran Bahasa Indonesia pada pokok bahasan karangan deskripsi.
Selama proses tindakan kelas dilakukan, peneliti sebagai guru yang melaksanakan proses pembelajaran dengan menggunakan model pembelajaran Contextual Teaching and Learning (CTL) diamati oleh guru kelas $\mathrm{V}$ yang bertindak sebagai observer/pengamat. Guru kelas VA mengamati peneliti dari awal proses pembelajaran berlangsung sampai akhir pembelajaran dan guru kelas $\mathrm{V}$ juga mengamati berdasarkan lembar observasi kemampuan guru dalam menerapkan model pembelajaran Contextual Teaching and Learning (CTL).

\section{Pembahasan}

Penelitian yang dilakukan di kelas VA SD Negeri 101766 Bandar Setia pada materi ajar keterampilan karangan deskripsi dengan menggunakan model pembelajaran Contextual Teaching and Learning dilakukan sebanyak dua siklus dan masing-masing siklus terdiri dari 2 kali pertemuan, yakni siklus I pertemuan I dan pertemuan II dan siklus II pertemuan I dan pertemuan II. Berdasarkan hasil penelitian menunjukkan bahwa penggunaan model pembelajaran Contextual Teaching and Learning dapat meningkatkan keterampilan menulis siswa.

Nilai rata-rata pada tes awal (pretest) adalah 61,73 dan pada siklus I meningkat menjadi 70,76. Namun pada siklus I belum memenuhi kriteria ketuntasan klaksikal sehingga dilakukan siklus II dan diperoleh nilai rata-rata 80,00. 
Erlinda Simanungkalit, Riri Dwi Putri : Meningkatkan ...

Jumlah siswa yang tuntas rata-rata keterampilan menulis jugameningkat di tiap-tiap tindakan yaitu dengan jumlah masing-masing adalah 9 siswa, 17 siswa, dan 23 siswa. Nilai tertinggi siswa juga meningkat di setiap siklusnya yaitu karangan deskripsi siswa, jumlah ketuntasan siswa, dan perolehan nilai tertinggi siswa di masing-masing tindakan dapat divisualisasikan pada diagram berikut ini.

75,00, 85,00 dan 95,00. Peningkatan

Tabel 1. Persentase Ketuntasan Keterampilan Menulis Karangan Deskripsi Pada Pretest, Posttest I dan Posttest II

\begin{tabular}{c|c|c|c|c}
\hline No. & Tahapan & Tingkat Ketuntasan & Jumlah Siswa & Persentase \\
\hline \multirow{2}{*}{1.} & Pretest & Tuntas $\geq 70$ & 9 & $34,61 \%$ \\
\cline { 3 - 5 } & & Tidak Tuntas $\leq 70$ & 17 & $65,38 \%$ \\
\hline \multirow{2}{*}{2.} & Tuntas $\geq 70$ & 17 & $65,38 \%$ \\
\cline { 3 - 5 } & Posttest I & Tidak Tuntas $\leq 70$ & 9 & $34,61 \%$ \\
\hline \multirow{2}{*}{} & Posttest II & Tuntas $\geq 70$ & 23 & $88,46 \%$ \\
\hline & & Tidak Tuntas $\leq 70$ & 3 & 11,53 \\
\hline
\end{tabular}

Dari tabel di atas dapat diketahui tingkat ketuntasan keterampilan menulis padapretest terdapat 9 siswa dinyatakan tuntas $(34,61 \%)$ dan tidak tuntas 17 siswa (65,38\%). Selanjutnya pada Posstest siklus I 17 siswa $(65,38)$ dinyatakan tuntas melewati KKM dan 9 siswa $(34,61 \%)$ tidak tuntas dan pada siklus II tes posttest II 23 siswa $(88,46 \%)$ telah tuntas dan selebihnya 3 siswa $(11,53 \%)$ dinyatakan belum tuntas sampai siklus II berakhir.

\section{Grafik 1. Peningkatan Dan Penurunan Keterampilan Menulis Karangan Deskripsi Siswa Berdasarkan Kategori}

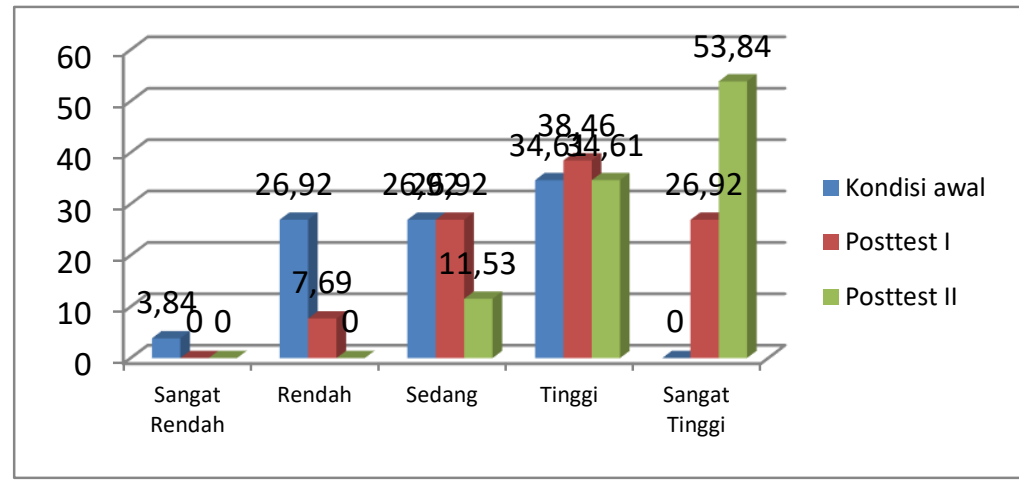

Pada grafik di atas menunjukkan bahwa kategori nilai mengalami peningkatan disetiap tahapnya. Seperti pada tahap kondisi awal kategori persentase sangat rendah $3,84 \%$, rendah $26,92 \%$, sedang $26,92 \%$, tinggi $24,62 \%$ dan sangat tinggi $0,00 \%$. Sedangan pada 
tahap posttestI persentase sangat rendah $0,00 \%$, rendah $7,69 \%$, sedang $26,92 \%$, tinggi $38,46 \%$ dan sangat tinggi 26,92\%. Sedangkan Posttest II persentase sangat rendah $0,00 \%$, rendah $0,00 \%$, sedang $11,53 \%$, tinggi $34,61 \%$ dan sangat tinggi $53,84 \% \%$. Disetiap tahap pada kondisi awal, posttest II dan Posttest II mengalami peningkatan disetiap kategori. Menandakan bahwa dengan menggunakan model pembelajaran Contextual Teaching and Learning dapat meningkatkan kategori nilai menjadi lebih baik.

Persentase aktivitas siswa di masing-masing siklus I 56,42\% dan $70,97 \%$. Pada siklus II adalah $80,90 \%$ dan $84,20 \%$ dari gambar diagram tersebut bahwa keberhasilan proses aktivitas siwa mengalami peningkatan.maka dapat disimpulkan bahwa penggunaan model pembelajaran Contextual Teaching and Learning (CTL) dapat meningkatkan keterampilan menulis karangan deskripsi siswa pada kelas V SD Negeri 101766Bandar Setia T.A 2017/2018.

\section{SIMPULAN}

Berdasarkan hasil penelitian
dari tiap-tiap siklus dapat
disimpulkan bahwa penggunaan
model pembelajaran Contextual Teaching and Learning (CTL)dapat meningkatkan keterampilan menulis karangan deskripsi siswa di Kelas V SD Negeri 101766 Bandar Setia. Peningkatan keterampilan menulis karangan deskripsi siswa dapat dibuktikan dari hasil karangan deskripsi siswa (nilai rata-rata dan ketuntasan klaksikal) dan aktivitas siswa berdasarkan hasil pretest, posttest siklus I, dan posttest siklus II.Serta observasi peneliti yang juga mendukung keberhasilan keterampilan menulis karangan deskripsi siswa.

Sebelum diberikan tindakan dari hasil pretest diperoleh rata-rata keterampilan awal siswa sebesar 61,73. Setelah dilakukan tindakan siklus I dari hasil posttest I diperoleh peningkatan nilai rata-rata menjadi 70,76. Selanjutnya, dari hasil posttest siklus II diperoleh nilai rata-rata meningkat menjadi 80.00.Persentase ketuntasan siswa secara klasikal sebelum diberikan tindakan/pretest sebesar 34,61\%. Pada siklus I persentase ketuntasan siswa secara klasikal dari hasil posttest I meningkat menjadi $65,38 \%$. Setelah dilakukan perbaikan pada siklus II, dari hasil posttest II persentase ketuntasan siswa secara klasikal mengalami peningkatan menjadi $88,46 \%$.

Aktivitas siswa selama proses pembelajaran sudah tergolong baik atau aspek yang diamati berdasarkan format lembar observasi yang ada mengalami peningkatan dari siklus I pertemuan I $(56,42 \%)$, pertemuan II $(70,97 \%)$ dan ke siklus II yaitu pertemuan I $(80,90 \%)$ dan pertemuan II (84,20\%). Aktivitas peneliti selama proses pembelajaran sudah tergolong baik atau aspek yang diamati berdasarkan format lembar observasi yang ada seluruhnya telah dilaksanakan 


\section{DAFTAR RUJUKAN}

Asul, Wiyanto. 2004. Menulis Paragraf. Jakarta: Gramedia Widiasarana Indonesia.

Agus, Suprijono. 2009. Cooperative Learning Teori dan Aplikasi PAIKEM. Yogyakarta: Pustaka Belajar.

Dalman. 2015. Keterampilan Menulis. Jakarta: Raja Garfindo Persada.

Dewi, Rosmala. 2015. Penelitian Tindakan Kelas. Medan: Unimed Press.

Emzir, 2015. Metodologi Penelitian Pendidikan. Depok: Raja Grafindo Persada.

Hamzah B. Uno. 2011. Teori Motivasi dan Learning, (Alih bahasa: Ibnu Setiawan). Bandung: Mizan Learning Center (MLC).

Ibnu, Badar. 2014. Mendesain Model Pembelajaran Inovatif, Progresif, Dan Kontekstual. Jakarta: Prenadamedia Group.

Indrawati. 2011. Model-model Pembelajaran. Jember: Universitas Jember.

Johnson, Elaine. 2014. Contextual Teaching And Learning (CTL). Bandung: Penerbit Kaifa.

Lamuddin, Finoza. 2009. Komposisi Bahasa Indonesia Untuk Mahasiswa Nonjurusan Bahasa. Jakarta: Diksi Insan Mulia

Mardiyah. 2016. Keterampilan Menulis Bahasa Indonesia Melalui Kemampuan Mengembangkan Struktur Paragraf. Jurnal Penddikan Dan Pembelajaran Dasar.
Lampung: Jurnal Pendidikan dan Pembelajaran Dasar. Vol 4, No. 2: 261-281.

Muslich, Masnur. 2009. KTSP. Pembelajaran Baerbasis Kompetensi dan Kontekstual. Jakarta: Bumi Aksara.

Nursisto. $1990 . \quad$ Penuntun Mengarang. Yogyakarta: Adi Cipta.

Riduwan dan Akdon. 2007. Rumus dan Data dalam Analisis Statistika. Bandung: Alfabeta.

Sanjaya, Wina. 2013. Strategi Pembelajaran. Jakarta: Kencana.

Soemarjadi, Muzni Ramanto, dan Wikdati Zahri. 2011. Pendidikan Keterampilan. Malang: Universitas Negeri Malang.

Suprijono, Agus. 2010. Cooperative Learning. Yogyakarta: Pustaka Pelajar.

Susanto, Ahmad. 2014. Pengembangan Pembelajaran. Jakarta: Prenadamedia Group. 